\title{
Tissue development in slaughter lambs of different genotypes ${ }^{1}$
}

\author{
Desenvolvimento tecidual em cordeiros de diferentes genótipos em terminação
}

\author{
ASSIS, Dallyson Yehudi Coura de ${ }^{2 *}$; SOUSA, Wandrick Hauss de ${ }^{3}$; CARTAXO, Felipe \\ Queiroga $^{3}$; RAMOS, João Paulo de Farias ${ }^{3}$; PAIVA, Gutemberg Nascimento ${ }^{2}$; \\ ALBUQUERQUE, Italo Reneu Rosas de ${ }^{2}$
}

\footnotetext{
${ }^{1}$ Parte da Dissertação do primeiro autor, financiada pelo BNB/Fundeci.

${ }^{2}$ Universiddae Federal da Paraíba, Centro de ciências Agrárias, Programa de Pós-Graduação em Zootecnia, Areia, Paraíba. Brasil.

${ }^{3}$ Empresa de Pesquisa Agropecuária da Paraíba, João Pessoa, Paraíba, Brasil.

*Endereço para correspondência: dcoura2@hotmail.com
}

\section{SUMMARY}

This study aims to evaluate the tissue development through real time ultrasound of lambs before slaughter in feedlot. It has been used thirty non-castrated lambs; being 10 Dorper $\mathrm{x}$ undefined breed, 10 Santa Inês $\mathrm{x}$ undefined breed and 10 undefined breed. The experimental units were about 120 days of age and $19,31 \mathrm{~kg}$ weight of in average. The lambs have received a single and complete diet, containing $15,5 \%$ of crude protein and 2,58 $\mathrm{Mcal} / \mathrm{kg}$ of dry matter. It has not been observed significant effect among the genotypes for any analyzed feature in the beginning of the experiment; however, there was influence of the genotype at the $28^{\text {th }}$ days in feedlot, for the body score, rib eye area and muscularity, in which the lambs Dorper x undefined breed were superior to the undefined breed. It has been verified the same effect at the 56 days in feedlot. The undefined breed lambs have presented higher marbling score than the others. There was positive linear correlation between the growing behavior of Longissimus dorsi muscle and adipose tissues with the time in days in feedlot.

Keywords: Dorper, sheep, ultrasound

\section{RESUMO}

Objetivou-se com este trabalho avaliar o desenvolvimento tecidual por ultrassonografia em tempo real de cordeiros terminados em confinamento. Foram utilizados 30 cordeiros inteiros, sendo10 Dorper x Sem Raça Definida (SRD), 10 Santa Inês x SRD e 10 SRD, com 120 dias de idade média e peso médio de $19,31 \mathrm{~kg}$. Os cordeiros receberam dieta única e completa, contendo $15,5 \%$ de proteína bruta e $2,58 \mathrm{Mcal} / \mathrm{kg} \mathrm{MS}$. Não foi observado efeito significativo entre os genótipos para nenhuma característica analisadas no início do experimento, porém, houve influência do genótipo aos 28 dias de confinamento para o escore corporal, área de olho-de-lombo e musculosidade, em que os cordeiros Dorper $\mathrm{x}$ SPRD foram superiores aos SRD. Observou-se o mesmo efeito aos 56 dias de confinamento. Os cordeiros SRD apresentaram maiores escores para o marmoreio do que os demais cordeiros. Houve comportamento linear crescente de crescimento dos tecidos muscular e adiposo com aumento dos dias de confinamento.

Palavras-chave: Dorper, ovinos, utrassonografia

\section{INTRODUCTION}

In recent years, the goat farming in the Brazilian northeastern region is ceasing like extractive activity and becoming a productive and sustainable exploitation. No longer considered as an subsistence labor and becoming profitable because the demand of sheep and goat meat in the high purchasing social classes who prefer low fat meat. 
Tough, the productive chain is not organized yet due factors like irregularity of offers, high product prices, lack of food standardization which reflects in the softness, succulence, odor and flavor of the meat. This occurs mainly due the unfamiliarity on part of the producers producing meat of good quality and providing to the market carcasses of animals with advanced age although the undesirable physical, chemical and organoleptic features, making difficult the consumption of these meat.

According to Zapata et al. (2000), the meat composition and quality, are important characteristics to determine the acceptance of new breeds and crossings, besides the application of new handling methods and animal production systems.

Nowadays, the consumer is stealth in his purchase decisions, searching for a healthy diet and requiring standardized products, with good quality and regular price offer. It is known that the genotype is one of the main factors which affect the performance, the qualitative and quantitative features of the carcass and the quality of the lamb's meat.

The crossing of unknown breed (UB) genotype matrices with purebred ewes may be an alternative to improve the quantitative and qualitative aspects of sheep production in Brazil. According to Cartaxo et al. (2009), the UB genotype has been always used as mother breed in crossings; therefore, it is necessary to survey the productive and qualitative features of the UB genotype. Forward the UB genotype is adapted to the climatic conditions of the region where they live and may contribute in a singular way for the sustainable development of some producing units.
According to Cartaxo et al. (2011); for the loin eye area, the thickness of subcutaneous fat and the marbling are characteristics measured through ultrasound which are related to the daily weight gain, carcass yield, slaughter precocity, good flavor and meat succulence.

For this reason, this study aims to evaluate the tissues development through real time ultrasound of different lamb's genotypes kept in confinement for slaughter.

\section{MATERIAL AND METHODS}

The experiment was conducted at the Experimental Station of Dependencia, in the company's state-owned of Agricultural Research in Paraíba (PBEmepa) located in the town of Soledad, Cariri of Paraiba, with an altitude of 534 a.m.s.l. In this area the rainfall fluctuates around $350-500 \mathrm{~mm} /$ year and the temperature of $30^{\circ} \mathrm{C}$ in average annual. The length of the raining season was 77 days, from October to December in the year 2010 .

It had been used 30 non-castrated lambs, these had been acquired from different properties being cubs from different parents, these animals where distributed in 3 groups: 10 animals of Dorper $x$ UB genotype, 10 animals of Santa Inês $x$ UB genotype and 10 animals UB genotype with 120 days average of age and $19,31 \mathrm{~kg}$ of body weight in average at the beginning of the experiment. The experimental units were submitted into a completely randomized design, with three treatments and 10 repetitions per treatment.

The statistical model used was the following one: $\mathrm{Yij}=\mu+\mathrm{Gi}+\varepsilon \mathrm{ij}$. In which: $Y i j=$ The observed value of the 
studied dependent variable; $\mu=$ Population average; $\mathrm{Gi}=$ Effect of genotype $\mathrm{i} ; \quad \varepsilon \mathrm{ij}=$ random error associated to each observation. The averages had been compared by Tukey test in 5\% of error probability and a simple linear regression to evaluate the tissue development in the experimental units in evaluation.

In the beginning of the experiment, all the experimental units had passed through an adaptation period of 14 days where they had been firstly vaccinated against clostridial infection, through subcutaneous application of ivermectin $1 \%$ and were distributed into individual hutches of $80 \times 120$ centimeters, all those cages had free access to the feeders and water into the confinement system.

It has been used a unique and complete diet, whose nourish and chemical composition are shown in Table I. It was established a consumption of $5 \%$ of the living weight of dry matter, being readjusted and weighed daily depending on the $10 \%$ leftovers.

In the evaluation process to accomplish the experiment objetives, were carried out three evaluations (at the beginning of the experiment, in the 28 days and in the 56 days) through real time ultrasound, as well as the weight and the body score. The body score evaluation was made by two examiners according to described methodology by Cezar \& Sousa (2006). For the attribution of the body score had been made evaluations before slaughtering through visual examination and palpation of the lumbar region and in the insertion of the lamb's tail, with punctuation of 1 to 5 , with intervals of 0,5 .

The carcass evaluation features were through real time ultrasound, the ultrasound equipment was the ALOKA 500 , with acoustic probe of $12 \mathrm{~cm}$ and frequency of $3,5 \mathrm{Mhz}$ and silicone coupler, allowing perfect coupling of the transducer with the body of the animal. Before picking up the images, it has been proceeded a trichotomy from the region between $12^{\text {th }}$ and $13^{\text {th }}$ left thoracic vertebrae of the animal. After that, it had been placed gel in the back of the animal to provide better conductivity and to improve the quality of the images and the coupling of the transducer to the body of the animal.

Table 1. Chemical and nourish composition of the experimental diet

\begin{tabular}{|c|c|}
\hline \multicolumn{2}{|l|}{ Food composition } \\
\hline Maniçoba hay (g/kg) & 350,0 \\
\hline Milled corn $(\mathrm{g} / \mathrm{kg})$ & 370,00 \\
\hline Soy bean bran (g/kg) & 190,00 \\
\hline Wheat bran $(\mathrm{g} / \mathrm{kg})$ & 55,00 \\
\hline Soy bean oil (g/kg) & 20,00 \\
\hline Mineral salt* $(\mathrm{g} / \mathrm{kg})$ & 5,00 \\
\hline Limestone $(\mathrm{g} / \mathrm{kg})$ & 10,00 \\
\hline \multicolumn{2}{|l|}{ Chemical composition } \\
\hline $\mathrm{DM}(\mathrm{g} / \mathrm{kg})$ & 888,00 \\
\hline CP (g/kg) & 155,30 \\
\hline TDN (g/kg) & 713,60 \\
\hline ME (Mcal/kg MS) & 2,58 \\
\hline NDF (g/kg) & 361,30 \\
\hline $\mathrm{EE}(\mathrm{g} / \mathrm{kg})$ & 47,30 \\
\hline NFC (g/kg) & 400,20 \\
\hline $\mathrm{MM}(\mathrm{g} / \mathrm{kg})$ & 51,10 \\
\hline \multicolumn{2}{|c|}{ 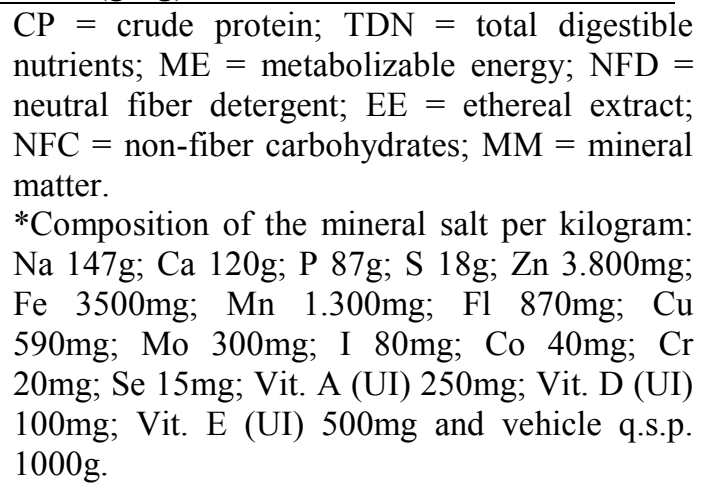 } \\
\hline
\end{tabular}

The probe equipped with acoustic guide was prepared in perpendicular way to the length of the muscle Longissimus 
dorsi, between the trichotomized vertebrae, for measuring the loin eye area (LEA) and the thickness of subcutaneous fat (TSF), was obtained at $3 / 4$ away from the medial side of the muscle Longissimus dorsi for the lateral of the dorsal line, and parallel, to get the marbling of the muscle Longissimus dorsi (scale from 0 to 10) through the software of carcass evaluation BIA PRO PLUS, of the Company Designer Genes Technologies.

It had been calculated muscularity (MUS) regarding the relation $100 \mathrm{~kg}$ of living weight, through ultrasound in vivo, using the formula MUS= LEA/PV $\mathrm{x} 100$, as described in the methodology by Cartaxo et al. (2011).

\section{RESULTS AND DISCUSSION}

It's observed none statistical difference between the genotypes for the initial weight (Table 2). This uniformity at the beginning of the experiment assists in understanding the development of the tissues.

Regarding the body score, there was no statistical difference between the genotypes; these values classify the lambs as slightly lean. These low scores are related to the breeding system which is predominant in the Brazilian Northeast region at the extensive livestock production system and in the period of the year; due the edaphoclimatic conditions, the pastures present low quality.

Table 2. Living Body Weight, Body Score, loin eye area (LEA), Thickness of Subcutaneous Fat (TSF), marbling (MAR) and muscularity (MUS) at the beginning of the confinement, depending on genotypes

\begin{tabular}{lccccc}
\hline \multirow{2}{*}{ Item } & \multicolumn{3}{c}{ Genotype } & \multirow{2}{*}{ P Value } & \multirow{2}{*}{ CV (\%) } \\
\cline { 2 - 4 } & Dorper x UB & SI x UB & UB & & \\
\hline Living weight $(\mathrm{kg})$ & $19,44 \pm 0,74$ & $19,70 \pm 1,38$ & $18,80 \pm 1,07$ & 0,196 & 5,759 \\
Body score $(1-5)$ & $2,44 \pm 0,30$ & $2,05 \pm 0,43$ & $2,15 \pm 0,33$ & 0,070 & 16,559 \\
LEA (cm $\left.{ }^{2}\right)$ & $6,16 \pm 0,58$ & $6,08 \pm 0,96$ & $5,52 \pm 0,59$ & 0,134 & 12,518 \\
TSF (mm) & $0,77 \pm 0,14$ & $0,88 \pm 0,17$ & $0,81 \pm 0,23$ & 0,465 & 23,319 \\
MAR (0-10) & $3,04 \pm 0,75$ & $2,89 \pm 0,56$ & $3,29 \pm 0,43$ & 0,333 & 19,333 \\
MUS (REA/PV)*100 & $31,69 \pm 2,39$ & $30,83 \pm 3,97$ & $29,44 \pm 3,20$ & 0,325 & 10,590 \\
\hline
\end{tabular}

Means and Standar Deviation followed by capital letters in the line differ by Tukey test $5 \%$ of significance for each parameter LEA= loin eye area in.

$\mathrm{SI}=$ Santa Inês and $\mathrm{UB}=$ undefined breed.

There wasn't found any relevant effect of the genotype above the loin eye area. This may be explained due the resemblance in the weights, it is known that the same influences affect directly in the loin eye area and denotes that the studied genotypes had presented similar muscular development. Ítavo et al. (2009) found superior values with 8,15 $\mathrm{cm}^{2}$ in UB genotypes lambs with average in body weight of $20,45 \mathrm{~kg}$; that probably assumed by the biggest initial weight in this experimental assay.

The thickness of subcutaneous fat was not influenced by the genotype, being coherent with the result found in the body score. The subcutaneous fat is directly related to the body score, in this way; Cartaxo \& Sousa (2008) explained significant correlation between the body 
condition and the thickness of subcutaneous fat in lambs.

Ítavo et al. (2009) obtained superior values for the thickness of subcutaneous fat working with UB genotypes of lambs presenting thickness of subcutaneous fat in the beginning of the experiment of $2,32 \mathrm{~mm}$. Thus; we conclude that the thickness of subcutaneous fat is closely correlated with body condition scores, as evaluated genotypes showed no effect on these variables, and showed homogeneity in ages, young animals have a lower fat deposition in relation to older animals, maybe that's the explanation for Ítavo et al. (2009) have found higher values than those shown in Table 2.

The marbling was not influenced by the genotypes, this characteristic is fundamentally important; therefore it determines the flavor and the succulence in the meat, which are determinative in the softness and quality of the product. The genotypes Dorper $\mathrm{x}$ UB, Santa Inês x UB and the UB had shown the score values of $3,04,2,89$ and 3,29 respectively. Calkins et al. (1981) found significant correlation between the rate of marbling and the tenderness of the meat, corroborating studies by Zeola et al. (2007) stated that obtaining beef with high marbling will consequently have a superior softness.

There was no statistical difference between genotypes for muscling, because the calculation of this variable are used to loin eye area and body weight, whit that, this where do not suffer from interference or influence of genotype, is the explanation for this result.

The living body weight in 28 days old lambs had not suffered any effect from due the genotype (Table 3). This demonstrates that the genotypes had presented similar weight gain during the related period of confinement.

Table 3. Living weight, body score, loin eye area (LEA), thickness of subcutaneous fat (TSF), marbling (MAR) and muscularity (MUS) in 28 days confined, depending on the genotypes

\begin{tabular}{|c|c|c|c|c|c|}
\hline \multirow{2}{*}{ Item } & \multicolumn{3}{|c|}{ Genotype } & \multirow{2}{*}{ Value $\mathrm{P}$} & \multirow{2}{*}{$\begin{array}{l}\text { CV } \\
(\%)\end{array}$} \\
\hline & Dorper x UB & SI $x$ UB & UB & & \\
\hline Living weight (kg) & $25,93 \pm 2,89$ & $27,26 \pm 2,18$ & $24,64 \pm 1,97$ & 0,063 & 9,110 \\
\hline Body score (1-5) & $3,22 \pm 0,26^{\mathrm{a}}$ & $2,80 \pm 0,34^{\mathrm{b}}$ & $2,65 \pm 0,24^{\mathrm{b}}$ & 0,0007 & 10,077 \\
\hline $\operatorname{LEA}\left(\mathrm{cm}^{2}\right)$ & $9,09 \pm 0,94^{\mathrm{a}}$ & $9,00 \pm 0,73^{\mathrm{a}}$ & $7,67 \pm 0,68^{\mathrm{b}}$ & 0,0006 & 9,227 \\
\hline $\mathrm{TSF}(\mathrm{mm})$ & $1,17 \pm 0,24$ & $1,19 \pm 0,17$ & $1,08 \pm 0,21$ & 0,537 & 18.645 \\
\hline $\operatorname{MAR}(0-10)$ & $3,17 \pm 0,66$ & $2,98 \pm 0,83$ & $3,48 \pm 0,62$ & 0,306 & 22,237 \\
\hline MUS (LEA/PV)*100 & $35,15 \pm 2,27^{\mathrm{a}}$ & $33,11 \pm 2,68^{\mathrm{ab}}$ & $31,16 \pm 1,95^{\mathrm{b}}$ & 0,003 & 7,025 \\
\hline
\end{tabular}

Averages followed by capital letters in the line differ by Tukey test $5 \%$ of significance for each parameter LEA $=$ loin eye area in.

$\mathrm{SI}=$ Santa Inês and $\mathrm{UB}=$ undefined breed.

The body score values shown statistical difference among the genotypes, where the genotype Dorper $x$ UB got greater score $(3,22)$ compared to Santa Inês $x$ UB $(2,80)$ and the UB $(2,65)$, demonstrating the aptitude of genotype in meat production, therefore there was greater growth of the tissues in 28 days of confinement in relation to the others genotype. 
The lambs Dorper x UB and Santa Inês $x$ UB had presented greater loin eye area than the UB genotype. This denotes that the lambs Dorper $\mathrm{x} U \mathrm{Ub}$ and Santa Inês $x$ UB had gotten greater muscular growth in 28 days than the UB genotype. These results show that lambs of the breed Dorper $x$ UB and Santa Inês $\mathrm{x}$ UB got greater ratio of the muscular tissue than the UB genotype, despite of showing similar weights.

According to Prado et al. (2004) the loin eye area is used as an indicative of muscular development, and Cartaxo \& Sousa (2008) obtained that the loin eye area indicates the ratio of muscle in the carcass.

It wasn't statistical difference between the genotypes for the thickness of subcutaneous fat; this suggests that after 28 days of confinement the lambs had deposited adipose tissue in the carcass in similar way, varying from $1,08 \mathrm{~mm}$ to $1,19 \mathrm{~mm}$. Superior results were reported by Amaral et al. (2010) that evaluating the fat tissue deposition in lambs Santa Inês, Dorper x Santa Inês and White Dorper x Santa Inês; evaluated through ultrasound and slaughtered with three thicknesses of fat $(2,0 ; 2,5$ and $3,0 \mathrm{~mm})$ with $26,20 \mathrm{~kg}$ of body weight, tough; it was verified that in 25,50 days of confinement the lambs reached $2,0 \mathrm{~mm}$ of fat thickness. The biggest energetic concentration $(77.59 \%$ TDN) from the diet in these animals was the influence for the biggest adipose tissue deposition in a lower period of confinement. For Clementino et al. (2007) the increasing of the available energy in the diet favors the biggest percentage of subcutaneous and inter-muscular fat in lambs.

In the diet of this experimental assay, were suministrated the same energy level to be tested between groups in evaluation; they showed no effects on the variables, as quoted by Clementino et al. (2007), the energy levels alters the deposition of fat in the carcass and meat where there may be greater juiciness and tenderness of meat. But in relation to muscle development genotypes Dorper $x$ UB and UB x Santa Inês expressed their genetic improvement for this variable; is noted the combined genetic like an animal factor and proper nutrition for optimal development of the animal.

The genotypes weren't differentiated by the marbling in 28 days of confinement. However, it has been observed that the values found, showed some increase with the confinement along the days, suggesting that the intra-muscular fat deposition be also influenced by the confinement period.

In the same way, was found that the genotype influenced on the muscularity performance, in which lambs, Dorper $\mathrm{x}$ UB genotype and Santa Inês $x$ UB genotipe with superior results above the UB genotype. This occurred due the lambs Dorper x UB and Santa Inês x Ub have greater loin eye area in 28 days at confinement than the UB genotype. Cartaxo et al. (2008) explained that the increase of the muscularity is not only related to the Longissimus dorsi muscle weight but also for the size of loin eye area.

Regarding the weight of the animals in 56 days, there was no statistical difference between genotypes (Table 4). This may be explained by the genetic variety of the UB that present like a fusion of different breeds in a single animal, then; being able to have genes of breeds' features for meat production. Similar results had been described by Cartaxo et al. (2011) that found values varying from 36.61 to $35,50 \mathrm{~kg}$ of body weight for the genotypes Santa Inês, Dorper x Santa Inês and Santa Inês x UB after 63 days of confinement. 
Table 4. Living weight, body score, loin eye area (LEA), thickness of subcutaneous fat (TSF), marbling (MAR) and muscularity (MUS) in 56 days of confinement, depending on the genotypes

\begin{tabular}{lccccc}
\hline \multirow{2}{*}{ Item } & \multicolumn{3}{c}{ Genotype } & \multirow{2}{*}{ Value P } & \multirow{2}{*}{ CV (\%) } \\
\cline { 2 - 4 } & Dorper x UB & SI x UB & UB & & \\
\hline Living weight $(\mathrm{kg})$ & $31,73 \pm 3,41$ & $32,12 \pm 1,98$ & $29,02 \pm 2,92$ & 0,042 & 9,092 \\
Body score (1-5) & $3,38 \pm 0,33^{\mathrm{a}}$ & $2,90 \pm 0,39^{\mathrm{b}}$ & $2,70 \pm 0,25^{\mathrm{b}}$ & 0,0004 & 11,175 \\
LEA (cm $\left.{ }^{2}\right)$ & $11,10 \pm 1,18^{\mathrm{a}}$ & $10,81 \pm 0,76^{\mathrm{a}}$ & $9,49 \pm 0,83^{\mathrm{b}}$ & 0,0017 & 8,989 \\
TSF (mm) & $2,15 \pm 0,41$ & $1,97 \pm 0,52$ & $1,83 \pm 0,42$ & 0,344 & 23,347 \\
MAR (0-10) & $3,00 \pm 0,52^{\mathrm{a}}$ & $3,10 \pm 0,59^{\mathrm{b}}$ & $3,80 \pm 0,46^{\mathrm{b}}$ & 0,004 & 16,042 \\
MUS (LEA/PV)*100 & $35,08 \pm 2,62$ & $33,72 \pm 2,19$ & $32,75 \pm 1,14$ & 0,065 & 6,094 \\
\hline
\end{tabular}

Averages followed by capital letters in the line differ by Tukey test $5 \%$ of significance for each parameter LEA = loin eye area in.

$\mathrm{SI}=$ Santa Inês and $\mathrm{UB}=$ undefined breed.

The body score was influenced by the genotype showing score values of 3,38 ; 2,90 and 2,70 for lambs Dorper x UB genotype, Santa Inês x UB genotype and UB genotype, respectively. This result demonstrates that the animals obtained of the Dorper x UB genotype breed, expressed their capacity of muscular and adipose tissue development better than the other genotypes in the present experiment. The body score is a subjective evaluation to estimate the muscular and adipose tissue amount in the animals, varying from 1 to 5 in which one is excessively lean and five excessively fat. The body scores observed in the present study may be classified as intermediate body condition according to Cartaxo et al. (2008). According to these authors lambs slaughtered in this condition have presented lower consumption of dry matter, excellent alimentary conversion, low number of days in confinement and greater gross margin, being able to be praised as criterion for lambs slaughtering.

The genotypes had influence on the development of the loin eye area, is was observed at the 56 days in confinement that the lambs Dorper $x$ UB and the
Santa Inês x UB showed greater loin eye area compared to the UB genotype, this indicates the lambs Dorper $x$ UB and the Santa Inês x UB from 28 days (Table III) until 56 days these genotypes presented superiority of the muscular tissue deposition.

Also was found the effect of the genotypes on the thickness of subcutaneous fat, despite the body score has been different, it was not enough to reflect bigger fat deposition in the carcass of the animals. A factor that could have influenced is the small subcutaneous adipose tissue deposition in the non-wooly sheep, that according to Cezar \& Sousa (2006) this tissue in the tropical non-wooly sheep and in goats is little developed, being almost all deposited in the body cavities.

The UB genotype lambs had presented superior marbling than the Dorper $\mathrm{x}$ UB and Santa Inês $x$ UB genotypes; this value could be influenced by the genetic variability of the UB used in the present study. This suggests that the marbling is influenced by the genotype that determines the improvement of this feature. This statement corroborates with the reports of Cartaxo et al. (2011) affirming that the marbling is not 
increased because the different levels of energy present in the diet offered, however, the genotype is determinative in the improvement of this characteristic.

The muscularity development was not affected for the genotypes in evaluation. The muscularity is related with the increase of the weight and the loin eye area size, however, it was expected that the biggest loin eye area gotten by lambs Dorper x UB and Santa Inês $x$ UB, would show higher muscularity.

In Figures (1, 2 and 3), regression equations expose the 3 genotypes in relation to the period of confinement $(0$, 28 and 56 days). It has been observed that there was a positive linear growth for muscular and adipose tissue with the increase of the days of confinement.

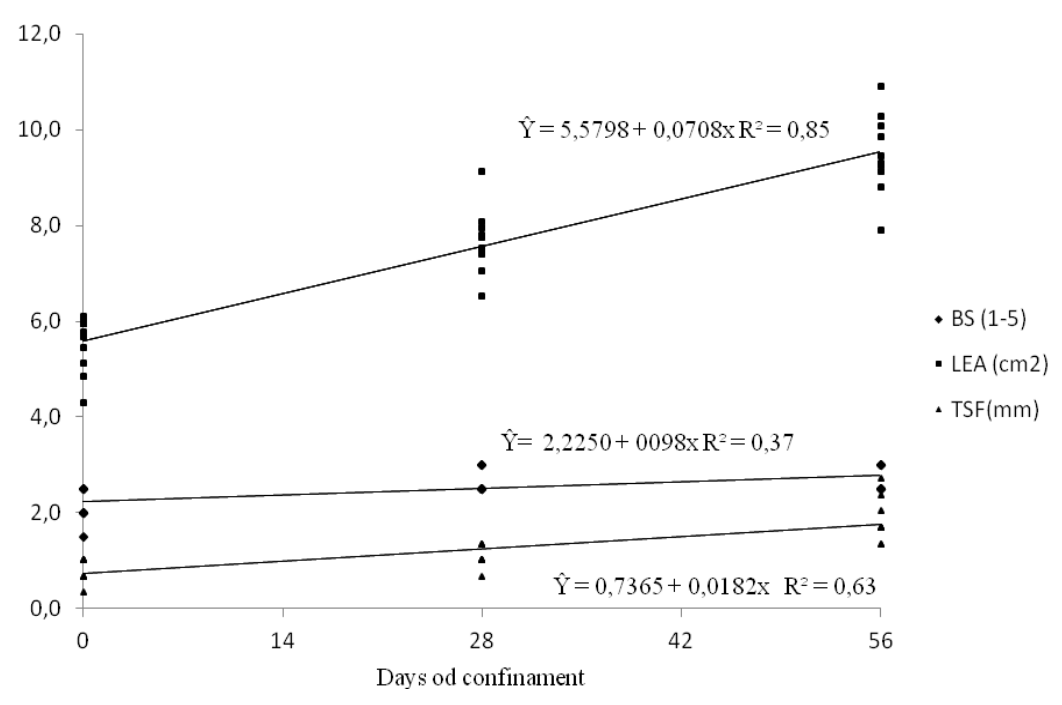

Figure 1. Regression equation of the loin eye area (LEA), thickness of subcutaneous fat (TSF) and body score (BS) of the UB genotype on confinement days

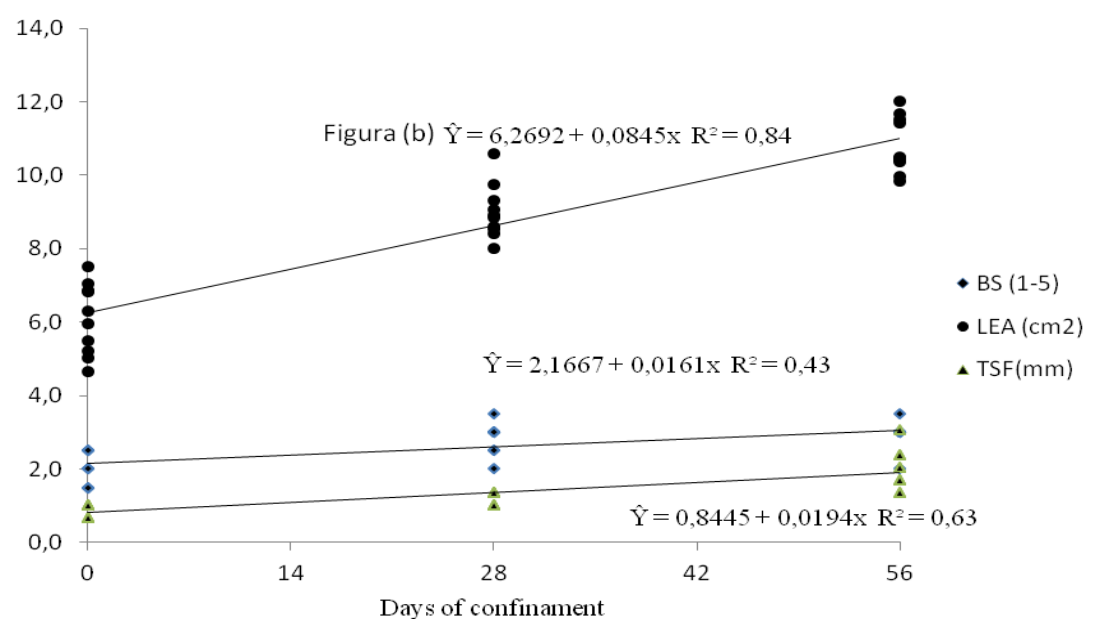

Figure 2. Regression equation of the loin eye area (LEA), thickness of subcutaneous fat (TSF) and body score (BS) Santa Inês x UB genotype on confinement days 


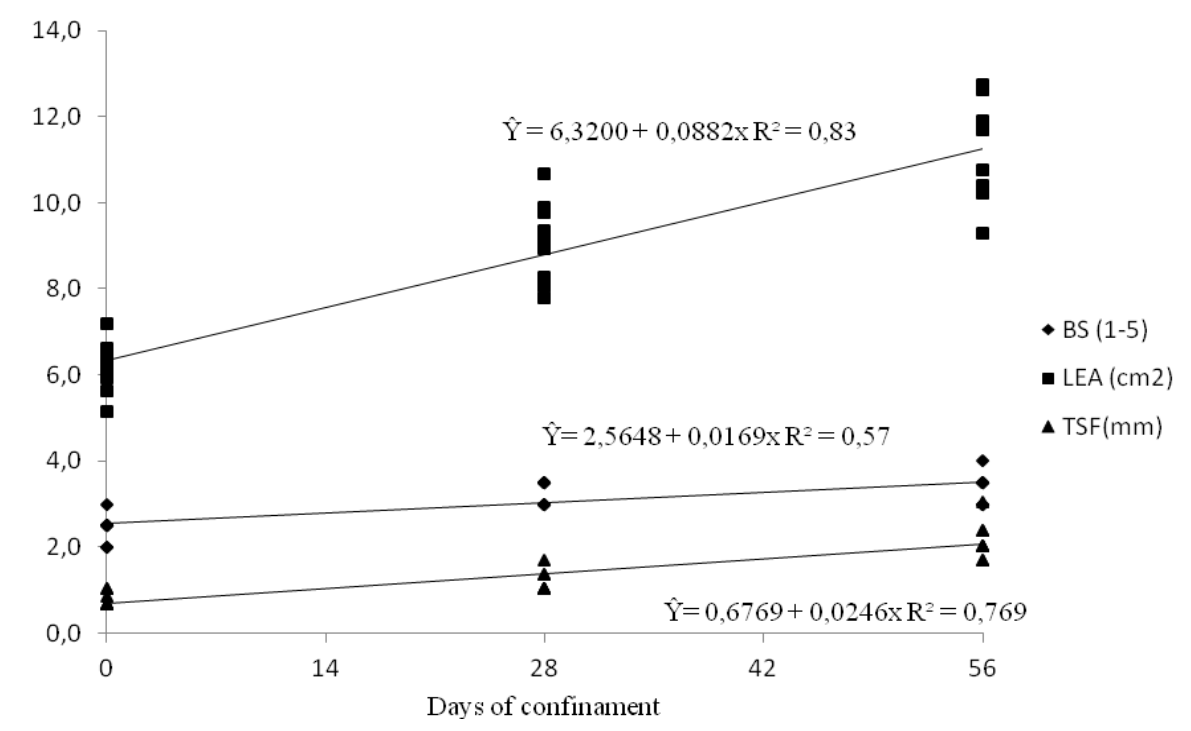

Figure 3. Regression equation of the loin eye area (LEA), thickness of subcutaneous fat (TSF) and body score (BS) Dorper $\mathrm{x}$ UB genotype on confinement days

Therefore, the number of days of confinement increases the values of the studied variable, however, it must be taken into consideration the maximum economic result regarding the confinement time. Cartaxo et al. (2008) reported the best relation cost/benefit gotten of lambs with intermediate body condition, with a gross margin of $28.8 \%$ superior to the one gotten in the fat body condition.

From the 28 days in confinement, the lambs Dorper $x$ UB present greater body score in relation to lambs Santa Inês $\mathrm{x} U \mathrm{Ub}$ and the UB, indicating precocity for slaughtering. The use of Dorper and Santa Inês breeds in the crossing with UB genotype improves the muscular tissue ratio, based on the loin eye area. There was linear behavior of the muscular and adipose tissue with the increase of the days of confinement.

\section{REFERENCE}

AMARAL, R.M.; MACEDO, F.A.F.; ALCALDE, C.R.; LINO, D.A.; BÁNKUTI, F.I,; MACEDO, F.G. de; DIAS, F.B,; GUALDA, T.P.

Desempenho produtivo e econômico de cordeiros confinados abatidos com três espessuras de gordura. Revista Brasileira Saúde Produção Animal. Salvador, v.12, n.1, p.155-165, 2011.

CALKINS, C.R.; DUTSON, T.R.; SMLTH, G.C.; CARPENTER, Z. L.; DAVIS, G.W. Relationship of fiber type composition to marbling and tenderness of bovine muscle. Journal of Food Science, v.46, n.3, p.708-7I3, 1981.

CARTAXO, F. Q.; SOUSA, W. H.; CEZAR, M.F.; NETO GONZAGA, S.; CUNHA, M.G.G. Efeitos do genótipo e da condição corporal sobre o desempenho de cordeiros terminados em confinamento. Revista Brasileira de Zootecnia. Viçosa, v.37, n.8, p.14831489, 2008. 
CARTAXO, F. Q.; SOUSA, W. H. Correlações entre as características obtidas in vivo por ultra-som e as obtidas na carcaça de cordeiros terminados em confinamento. Revista Brasileira de Zootecnia. Viçosa, v.37, n.8, p.1490-1495, 2008.

CARTAXO, F.Q.; CEZAR, M.F.; SOUSA, W.H.; NETO GONZAGA, S.; FILHO PEREIRA, J.M.; CUNHA, M.G.G. Características quantitativas da carcaça de cordeiros terminados em confinamento e abatidos em diferentes condições corporais. Revista Brasileira de Zootecnia. Viçosa, v.38, n.4, p.697704, 2009.

CARTAXO, F.Q; SOUSA, W.H.; CEZAR, M.F. COSTA, R.G.; CUNHA, M.G.G.; NETO GONZAGA, S.

Características de carcaça determinadas por ultrassonografia em tempo real e pós-abate de cordeiros terminados em confinamento com diferentes níveis de energia na dieta1. Revista Brasileira de Zootecnia. Viçosa, v.40, n.1, p.160167, 2011.

CEZAR, M.F.; SOUSA, W.H. Avaliação e utilização da condição corporal como ferramenta de melhoria da reprodução e produção de ovinos e caprinos de corte. Revista Brasileira de Zootecnia. Viçosa, v.35, p.541-565, (Suplemento especial), 2006.

CLEMENTINO, R.H.; SOUSA, W.H.; MEDEIROS, A.N.; CUNHA, M.G.G.; NETO GONZAGA, S.; CARVALHO, F.F.R.; CAVALCANTE, M.A.B. Influência dos níveis de concentrado sobre os cortes comerciais, os constituintes não-carcaça e os componentes da perna de cordeiros confinados. Revista Brasileira de Zootecnia. Viçosa, v.36, n.3, p.681688, 2007.
ÍTAVO, C.C.B.F.; MORAIS, M.G.; COSTA, C.; ÍTAVO, L.C.V.; MACEDO, F.A.F.; TOMICH, T.R. Características de carcaça, componentes corporais e rendimento de cortesde cordeiros confinados recebendo dieta com própolis ou monensina sódica.

Revista Brasileira de Zootecnia. Viçosa, v.38, n.5, p.898-905, 2009.

PRADO, C. S.; PÁDUA, J. T.; CORREA, M. P. C.; FERRAZ, J.B.S.; MIYAGI, E.S.; RESENDE, L.S. Comparação de diferentes métodos de avaliação da área de olho-de-lombo e cobertura de gordura em bovinos de corte. Ciência Animal Brasileira, v.5, n.3, p.141-149, 2006.

ZAPATA, J. F. F.; SEABRA, L. M. J.; NOGUEIRA, C. M.; BARROS, N.

Estudo da qualidade da carne ovina do Nordeste brasileiro: propriedades físicas e sensoriais. Ciência e Tecnologia de Alimentos, Campinas, v.20, p.274-277, 2000 .

ZEOLA, N. M. B., SOUZA, P. A., SOUZA, H. B. A., SILVA SOBRINHO, A. G. Parâmetros qualitativos da carne ovina: um enfoque à maturação e marinação. Revista Portuguesa de Ciências Veterinárias, 102 (563-564) 215-224, 2007.

Data de recebimento: 13/03/2013

Data de aprovação: 18/12/2013 